\title{
Overcoming Ethnic Conflict through Multicultural Education: The Case of West Kalimantan, Indonesia
}

\author{
Ayami Nakaya \\ Hiroshima University \\ Japan
}

ABSTRACT: This study examined the effectiveness of multicultural education provided after the ethnic conflict (1996-2001) in West Kalimantan, Indonesia. Research included textbook analysis, observation of practice, interviews with teachers and NGOs, and surveys of junior high school students' social identity. Multicultural education was found to help students understand the past and the multicultural situation in the present. However, two problems were identified: stakeholders' trauma and anxiety regarding teaching the negative past and critical thinking weaknesses, especially in terms of (re)producing prejudice and conflicts. Based on social identity analysis, this study recommends that multicultural education should be implemented under transformative citizenship education.

KEYWORDS: multicultural education, transformative citizenship education, ethnic conflict, local curriculum, social identity

Multicultural Education, Transformative Citizenship Education, and Social Identity Methods

Multiculturalism in Indonesia's Education System Post-conflict Multicultural Education in West Kalimantan

Students' Social Identity Notes

References

Author Contact

In the late 1990s, violent ethnic conflicts in Indonesia tended to occur during periods of institutional reform and renegotiation of the national model, especially after the fall of the Suharto regime in 1999 (Bertrand, 2004). In these ethnic conflicts, at least 10,000 people were killed nationwide between 1997 and 2002. In West Kalimantan, there were three main conflicts: in Sanggau Ledo (1996-1997), Sambas (1999), and Pontianak (2001). At least 1,000 people died in West Kalimantan, and more than 50,000 experienced incidents of ethnic violence (Prevent Conflict, 2002).

The main actors in these conflicts, the Madura and the Dayak, have a long history of conflict rooted in resource exploitation, inward migration, and social cohesion (Achwan, Nugroho, Prayogo, \& Hadi, 2005). The Dayak are an indigenous people living in a forest area, more than half of which has been 
exploited by the government. The Malay (the local majority ethnic group) and the Dayak regard the Madura as migrants who dominate the market as sellers, land and river transportation as porters, and the job market in the ports (International Crisis Group, 2001). However, both Dayak and Madura see cultural differences as more important than political or economic factors (Fanselow, 2015). The two groups harbor negative stereotypes about each other. For the Madura, Dayak are "lazy natives" who lack self-discipline and are envious of the "hard-working" and "rich" Madura. Dayak, meanwhile, view Madura as aggressive and prone to violence. There are also cultural clashes in terms of the Dayak adat (indigenous law) and the Madurese carok (the ritual restoration of self-esteem through violence).

Many countries have implemented educational tools-such as peace, human rights, religious, citizenship, and multicultural education-to overcome ethnic conflicts (Salomon \& Cairns, 2010; Fontana, 2016). In West Kalimantan, multicultural education was implemented to address ethnic conflicts. This was undertaken by nongovernmental organizations (NGOs) in collaboration with local governments, international institutions, and school teachers. The present study examines how such multicultural education might help to overcome ethnic conflicts and prevent future conflicts.

\section{Multicultural Education, Transformative Citizenship Education, and Social Identity}

The theoretical framework of this study is based on multicultural education, transformative citizenship education, and social identity theory.

Banks (2004) identified five dimensions of multicultural education: content integration, knowledge construction, equity pedagogy, prejudice reduction, and school and social structure empowerment. These dimensions indicate how multicultural education textbooks and teachers integrate multicultural content and help students to understand prejudice construction, authentic culture, social discrimination, and equity among ethnic groups, and thus develop positive racial attitudes.

Banks $(2008,2017)$ further explained how transformative citizenship education can build a multicultural democratic society. Transformative citizenship involves civic actions designed to actualize values and moral principles, such as human rights, social justice, and equality, beyond existing laws and conventions. Transformative citizenship education develops critical thinking and social action skills in students to identify societal problems and promote social justice that is implemented through transformative academic knowledge (2008). "Transformative academic knowledge consists of paradigms and explanations that challenge some of the key epistemological assumptions of mainstream knowledge" (Banks, Orozco, \& Peretz, 2016, p. 45). The purpose is to question the social, political, and economic structures within society that 
perpetuate inequality and contribute to the marginalization of excluded groups (2016). Transformative citizenship education helps students attain reflective cultural, national, regional, and global identification and comprehend the interrelations and constructions of these identities (Banks, 2008). It contributes to balancing unity and diversity, helping students maintain connection with their cultural communities as well as participating effectively in the shared national culture (Banks, 2009).

Social identity, the third concept in this framework, is created by media, society, traditional communities, religious communities, schools, regions, provinces, and nations. As such, social identity can give rise to prejudice and intolerance (Yuki, 2006). Therefore, education aimed at overcoming conflict should be developed based on the situation of students' social identity. Since junior high school students in the study area were born a few years after the ethnic conflicts, they live in a different situation from that of their parents. There are differences in their ways of thinking, lifestyles, and worldviews stemming from decentralization, democratization, rapid technological development, and globalization.

\section{Methods}

This study applied a sequential exploratory design (Creswell, 2013), which calls for an initial phase of qualitative data collection and analysis followed by a phase of quantitative data collection and analysis.

First, document analysis was applied to identify multiculturalism in Indonesia's educational system and analyze the effectiveness and efficiency of the multicultural education textbook used in West Kalimantan. Aliansi untuk Perdamaian dan Rekonsiliasi (ANPRI, 2008), a union for building peace and reconciliation comprising six NGOs, developed and published a multicultural education textbook for junior high schools in 2001 and revised it in 2008. The textbook was expected to be implemented and taught as a local subject in West Kalimantan. The 2008 textbook was assigned to first- to third-year junior high students. The textbook for the first year contains 120 pages, those for second and third years about 70 pages each, and all contain black-and-white photos. To understand the textbook, interviews were conducted with one staff leader of the group that published the textbook.

Second, two junior high schools that taught multicultural education were selected for class observation and interviews in March 2016. Both are private schools located in Pontianak, the capital of West Kalimantan. At that time, some private schools and seven public schools were known to have implemented multicultural education. School A had integrated it with other subjects such as music, social studies, and extracurricular classes. For this study, multicultural education in music class was observed. This was followed by an interview with 
the principal who taught multicultural education, had received training from the NGO, and had helped to improve the textbook, and also with the vice-principal. Meanwhile, School B had taught multicultural education two hours per week to first-year students since 2008. Interviews were conducted with the principal and the teacher who taught multicultural education.

Subsequently, a survey of junior high school students was conducted to shed light on their social identities, including national, ethnic, local, and global aspects. A survey was conducted with 107 junior high school students at School A in Pontianak in March 2016. Quantitative analysis was performed using SPSS 21 to determine uniqueness in national, ethnic, and local identities, as well as the recognition of globalization. Survey items regarding identity were borrowed from previous research and adapted for the Indonesian context. These refer to attributes and factors that might affect students' identity, gender, ethnic group, religion, native language, favorite TV program (Indonesian, Asian, and Western), and frequency of Internet use. Answers were provided on a Likert scale: $1=$ not at all, 2 = rare, $3=$ not so often, $4=$ often, $5=$ very often. The perception-of-effect factor was also given on a Likert scale: $1=$ strongly disagree, 2 = disagree, 3 = undecided, 4 = agree, 5 = strongly agree.

Previous research has developed measures to determine local/place identity, attachment to residence, pride, thought, and activities (Lewicka, 2008; Scannell \& Gifford, 2010). The present study focused on attachment to residence to compare it with other levels, since attachment is a crucial factor for development and social commitment (Obori, 2010). The question was, "Do you have an attachment to the place where you live?"

This study used the Multigroup Ethnic Identity Measure (Phinney \& Ong, 2007). The items were as follows, with short phrases created by the author for analysis:

1. I have spent time trying to find out more about my ethnic group, such as its history, traditions, and customs (spends time trying to find out more about ethnic group);

2. I have a strong sense of belonging to my ethnic group (strong sense of belonging);

3. I understand what my ethnic group membership means to me (understanding of ethnic group membership);

4. I often do things that will help me to better understand my ethnic background (often does things to understand ethnic background);

5. I often talk to other people to learn more about my ethnic group (talks to people to learn more about ethnic group); and

6. I feel a strong attachment to my ethnic group (attachment).

Researchers have defined national identity in various ways. Tanabe (2010) defined it broadly as the "general perception of interaction between 
people and nation" and categorized it into general conceptions of "condition of member of nation," "pride in nation," "nation-centrism," and "antiforeignism" (pp. 41-48). For comparison with other identities, this study asked, "Do you feel attachment to your nation?"

Regarding globalization, this study used six items from the East Asian Social Survey (Hamada, 2013):

1. Globalization is the increase in movement of people, materials, and money over nations and regions. Do you think this phenomenon is good for

(a) your country's economy (good for the economy),

(b) employment opportunities in your country (good for the labor market), and

(c) your country's environment (good for the nation)?

2. Regarding the relationship between Indonesia and other countries, what do you think about the

(a) need to control the importing of foreign products to protect the country's economy (need for import control);

(b) need to pursue the nation's own benefit, even if doing so increases tension with other countries (seeking national interest); and

(c) risk posed to the country's culture by increasing opportunities to consume foreign movies, music, and books (bad influence on culture)?

In relation to their sense of identity, participants were asked about having a sense of contribution as a reason for selecting a future job.

$+$

\section{Multiculturalism in Indonesia's Education System}

Before explaining the textbook analysis, I will briefly describe multiculturalism in Indonesia's educational system to clarify the context. Multiculturalism in Indonesian education was introduced after the country's independence as a fundamental principle of nationhood: Bhineka Tunggal Ika (unity in diversity). For example, the six main religions are taught in religious subjects, just as ethnic culture (including traditional houses and the clothing of various groups) is introduced in social studies and citizenship education subjects. This strategy aimed to cultivate a national identity for unifying such a multicultural nation. However, majority group cultures often appear in textbooks, and diversity is represented by the one majority culture of each province, in spite of the many ethnic groups in existence. Political content tends to be 
avoided, but "allowable culture" is included, even if such inclusion may not increase ethnic group identity (Katou, 1993, p. 34).

In 1994, local curricula were implemented in elementary and junior high schools, representing a major move toward decentralization in education. This was expected to produce, via the study of local traditional cultures and industries, graduates with a sense of local attachment and a commitment to local development. Provincial education offices developed the curricula while individual schools implemented both compulsory and noncompulsory local subjects (Nakaya, 1997, 2004). While there were many successful cases, controversy also arose regarding definitions of "local." When majority groups established compulsory subjects based on their own culture and language, minorities struggled in their studies. This unintentionally created discrimination among ethnic groups within the province. However, the 2006 curriculum (School-Based Curriculum) resolved these issues to some extent since schools were given the authority to develop their own curricula based on national standards and guidelines.

\section{Pre-conflict Multicultural Education in West Kalimantan}

The local curriculum on culture in West Kalimantan after 1994 included "traditional ethnic culture" and "tourism" subjects, implemented in junior high schools. At the time, there were no textbooks and no detailed guidelines or training for teaching. As this was a new curriculum, spreading it for implementation was slow, especially in schools far from the main city.

In previous ethnographic fieldwork in classrooms from 1995 to 1996 (Nakaya, 1997), I identified the possibility of decreasing prejudice against the Dayak in the presence of the following aspects related to the teacher: high motivation, an attitude of mutual understanding, and rich knowledge and actual activities related to cultural preservation as a member of the Dayak community. Through studying traditional Dayak law and custom (adat) using various types of interesting stories, students easily imagined their lifestyle, manner of treating guests, and appropriate matchmaking of partners. Teachers' humor, insight, and rich knowledge motivated students to learn more and treat the Dayak with respect. However, there was also a risk of increased prejudice when the following teacher-related aspects were present: no previous experience or knowledge of the Dayak, unconscious bias against the Dayak, and a lack of agreement to teach the subject due to a difference in specialty. The ethnic conflict in West Kalimantan occurred before this curriculum could be broadly implemented. 


\section{Post-conflict Multicultural Education in West Kalimantan}

Following the ethnic conflict, a series of activities were initiated in preparation for multicultural education, including collaboratively editing textbooks and training by NGOs, educators, local government, and international institutions. Subsequently, utilizing these textbooks and training, several junior high schools implemented multicultural education as a subject or integrated content in certain subjects. The section provides the author's analysis of the multicultural education textbooks, perceptions of NGOs and educators, and students' social identities.

\section{Textbook}

The introductory part of the multicultural education textbook explains that its aim is to develop peace through an understanding of and respect for different cultures.

In Chapter 1 (Multicultural Education), learners are challenged to understand multicultural education in general and in the local context (especially West Kalimantan). A sidebar reads, "Result of conflict: armed conflict in West Kalimantan destroyed individual lives. There were no winners and no losers. Everybody is a loser" (ANPRI, 2008, p. 4). After mentioning briefly the factors of conflict-including its political, economic, and cultural factors - the textbook narrates the long history of conflicts in West Kalimantan from 1962. It includes information about ethnic groups, places, periods of occurrence, examples of sacrificed people (especially children who lost houses and schools), and the existence of prejudice among the different groups, along with the attempt to create emotional understanding and empathy. The next part simply mentions examples of conflicts in other countries, emphasizing the effectiveness of multicultural education for solving long-term conflicts. Subsequently, it connects this context to that of West Kalimantan. "Why was multicultural education started? Because there was an armed conflict caused by differences in ethnicity, religion, tribes, social groups, skin color, and roots in this world, including West Kalimantan" (ANPRI, 2008, p. 5). The textbook's definition of multicultural education is "education about various kinds of cultures for increasing understanding, respect, and acceptance of various cultures," which "aims to spread tolerance" (ANPRI, 2008, p. 9). However, it lacks explanations of the political and economic factors that give rise to feelings of unfairness and prejudice among ethnic groups. To help students think critically and change the society to prevent next conflict as transformative citizens (Banks, 2017), the dynamics of how the conflicts occur should also be explained. 
At the end of Chapter 1, assignments are given as both individual work (writing about personal experiences with friends and neighbors) and group work (collecting clippings from the media and researching the traditional customs of ethnic groups in West Kalimantan). Such tasks "help to create equal status in the classroom by giving voice to the histories and experiences of all students in the class and by enabling all to experience equality and recognition" (Banks, 2008, p. 135; Gutmann, 2004) in ethnically mixed classes. However, these tasks might also cause students to form a negative image or confirm their prejudice if they learn about negative stories from friends, neighbors, or the media. Before assigning such activities, students should be trained to think about how information is created by individuals and media outlets through colored lenses. In this sense, the textbook's weakness in the "knowledge construction" dimension (Banks, 2004) is apparent. The textbook should also introduce the issues of how cultural violence perpetuates such prejudices and how structural violence leads to direct violence (Galtung, 1969) in society. This would help students understand how to take action in the real world, thereby preventing the negative knowledge reconstruction cycle by their own actions.

Chapter 2 (Introduction to Multicultural Education in West Kalimantan) provides a description of the multicultural situation in West Kalimantan, with historical background from the colonial period, statistical data and demographics on each ethnic group, a simple introduction of cultural markers (values, dresses, ceremonies, lifestyle, and buildings), and categorizations of sub-ethnic groups by region, history, and ethnic mixing by marriage. This chapter seemingly includes a discussion of the cultures of various ethnic groups; however, there are certain explanations that could reinforce stereotypes. For example, for the Dayak, the headhunting custom and its reasons-namely, to solve tensions between sub-ethnic groups, obtain a new parcel of land, acquire a partner for marriage, protect farmers, gain power, or seek revenge-are highlighted. While the textbook mentions that the custom was banned in the nineteenth century, it also contains a photo of the ceremony for the skulls following traditional rules. After this detailed explanation of headhunting, the chapter describes, suddenly, the kindness and open-mindedness of the Dayak. The connection with the previous content is tenuous, and students might have already formed the perception that "traditional" means savage or primitive or that headhunting is an exclusive custom. The chapter also shows photos of a child with traditional sagging earlobes with huge earrings and a traditional long house. While these photos might have been selected to show the authentic culture, there is a risk of reinforcing stereotypes, especially in contrast with representations of the Malay, with photos showing their beautiful costumes and lavish ceremonies. Regarding the Madura, after an explanation of their reasons for migrating from Madura Island, their strong sense of pride and group membership is emphasized. The textbook highlights the Madura custom of carok, which is an armed attack on enemies. The chapter states that carok is not a culture of the Madura but is on the spectrum of the "character of Madura." 
Such explanations, while highlighting the uniqueness of the ethnic groups, have potentially negatively effects in the sense that they evaluate a culture using the single measure of brutal to elegant, and leading to the reconstruction of negative images against of the Dayak and Madura.

Chapter 3 (Interaction among Multiethnic Societies in West Kalimantan) attempts to help students understand the concepts of assimilation, acculturalization, and integration. The chapter helps students understand the interaction of ethnic and religious communities that are mixed via marriage, using examples such as Malay and Dayak and Malay and ethnic Chinese, but no case of Dayak and Madura. Moreover, the explanations of their good relationships are made by using local tales, history, ceremonies, and an acceptance of Java culture (the majority of nation); there is no explanation of the situation regarding this assimilation or acculturalization or integration in their own lives, except for a student assignment where they are asked to listen to their families' and neighbors' stories. There is also no information on how equal status in their social lives can be assured through laws and systems. To become transformative citizens, students should receive more transformative academic knowledge (Banks, 2008), which could be applied to their daily lives to identify problems in society and bring successful and conflict-free integration.

From Chapter 4 onward, the textbook introduces cultural practices by major ethnic groups, such as the Dayak harvest ceremony, ceremonies of the Madura, and the doll theatre of the Java. Migrants' cultural influences are covered as well. However, it does not focus on "prejudice reduction" (Banks, 2004). The multicultural education textbooks for second- and third-year junior high school have the same features in Chapter 4 but with a more detailed explanation.

\section{Perceptions of NGOs and Educators}

The interview with the NGO staff leader yielded insights into the ideal process of NGO-led textbook production as well as the challenges to its ideal utilization in schools. The revised textbook (2008) came about after the stage of conflict shifted from reconciliation to tranquility. NGOs invited teachers from seven schools that showed interest in discussing the content, which was then revised based on trial implementation in those schools. The NGO staff leader indicated that the main revision was the inclusion of other conflict cases in Indonesia to help prevent future conflicts. However, he acknowledged that the revised book has limitations, such as the fact that factor analyses of the conflicts are not explained. Apart from the matter of the textbook itself, he regretted that the textbook is only "recommended" by the local government. The public schools needed to obtain permission from local authorities to start multicultural education in the local curriculum. Even though the School-Based Curriculum was launched in 2006, public schools felt it difficult to use the "recommended" 
book rather than the "compulsory" one. Therefore, multicultural education was not as widely implemented as NGOs had expected.

In School A, the principal had attended several workshops for multicultural education by NGOs and felt a responsibility to implement it. The school is an Islamic private school; they have a tight schedule of classes, as the curriculum includes additional Islamic subjects outside the national curriculum. Therefore, they try to integrate multicultural education into several subjects. The vice-principal emphasized that they would feel ashamed if students did not know their own traditional culture. His idea is a fundamental basis of multiculturalism: to know ourselves in order to understand others (Mansouri, 2009).

Regarding the textbook, the principal noted the difficulty in reaching consensus among local education authorities, parents, and teachers because of the sensitivity of the issues, especially for those still suffering trauma and those who have anxiety about the negative impact of this new educational material. This may be the reason why the local authority did not make the textbook compulsory.

Therefore, the principal (a Java migrant) integrated multicultural education into her music class but without using the textbook. When the author observed her class, she introduced multiculturalism as living together and respecting each culture, using multimedia presentations. First, she emphasized, through the singing of national songs, the importance of respecting every ethnic group's culture to maintain peace in society. Second, she introduced the concepts of peace in every religion, mainly Islam. Third, she introduced the music and dance of the many ethnic groups. The students enjoyed singing various ethnic songs.

In Indonesia, the national idea of Bhineka Tunggal Ika ("Unity in Diversity") is repeated on various occasions to establish a strong national identity as part of a national strategy to maintain unity. In her class, she practiced the same strategy but went beyond that because she introduced music from all ethnic groups in West Kalimantan, not just the majority groups. However, as hers was a music class, it could not delve into other cultural aspects (e.g., roots and dynamics) and socioeconomic issues faced by ethnic groups. She mentioned such keywords as responsibility, tolerance, caring, support for others, dedication, and empathy, albeit by showing the concepts only. Further discussion with contextualization for building a multicultural democratic society (Banks, 2008; Gutmann, 2004) is needed here.

In School B, half the students were ethnic Chinese while the others were Dayak and Malay. The teachers were mainly Dayak. According to the principal, conflicts among students are rare and never serious. Cases include the use of negative language toward other ethnic students; these are addressed by speaking directly with the student and the parents regarding the problematic behavior. 
The interviewed teacher (a Dayak) was highly motivated to implement multicultural education because of her own experience with conflict, which she remembers very well. She mainly taught economics in addition to multicultural education. After training by NGOs and self-study, as well as teaching and discussion with students, she recognized the importance of the issue and became interested in it.

She opted to use content from the textbook in her classes based on her own stance and her students' needs. She mentioned being worried about the deterioration of traditional culture and misunderstanding of students' own culture. She said, "Every culture has a good meaning, [but] we need to change the process or the way of implementation. The respected wisdom should be kept." She used the example of tattooing, which is prohibited now. Tattoos have meanings that can help students understand the Dayak worldview. Therefore, in class, she would explain the cultural philosophy involved, not just the tattoo itself. This practice could achieve the first aim of multicultural education, which is to promote an "awareness and appreciation of the students' own culture and the cultures of others" (Mansouri, 2009, p. 164).

Since many of the students are of mixed ethnic, linguistic, and even religious backgrounds, the teacher also aimed to connect the content of ethnic cultures and multicultural situations to students' lives. This involved activities such as making a dictionary of Bahasa Indonesian and the language of the students' parents. The teacher further asked students to discuss their families' stories-including the good and the bad-to help them understand their roots and the complexity of ethnicity. According to her, this exercise helped students to understand mixed ethnicities and coexisting religions. These two activities are noted in the textbooks.

Where she found evidence of difficulties or conflicts between the students' parents in their reports, the teacher coached students in their behavior. In one example, when she realized a student had lost his means of living because of conflicts between his parents and negative behavior by his father, she suggested that he strictly follow his mother's religion, which he opted to do. Nonetheless, reconciliation among family members may be complex and difficult to discuss in class with other students as a case study for multicultural understanding. In trying to find examples from students' families of mixed marriages, there is sometimes a tendency to understate actual difficulties, or some students will feel sad if the mixed family was not successful. As Sleeter (2016) noted, family history is useful for challenging national myths. It has the possibility of encouraging students to think critically about the reality of national multicultural policy as a step toward the realization of a multicultural democratic society. However, a method that uses family history can be a sensitive and challenging way of approaching this issue, especially for students of this age. This task of establishing a connection between the ideal of peace building and the reality of students' lives is very important; however, it places an 
unacceptable level of responsibility on the teacher, as Lauritzen and Nodeland (2017) have argued.

\section{Students' Social Identity: National, Ethnic, Local, and Global Perspectives}

To find ways to improve multicultural education, this section examines students' social identities and the factors affecting them.

\section{Results and Analysis}

The sample in this study consisted of junior high school students ( $\mathrm{n}=$ 107; 60 male and 47 female). The majority of respondents were Muslims (105); two did not provide their religion; there were no Catholic respondents. Regarding ethnicity, more than half were Malay (55.3\%), followed by mixed ethnicity (16.5\%, Dayak, Chinese, or other), Madura (13.6\%), Java (10.7\%), and Bugis (3.9\%).

Regarding the factors that affect the consciousness and opinion of students, Figure 1 shows that their parents were the strongest factor, followed by religion and teachers. This result suggests that these factors have a high possibility of either reinforcing stereotypes or increasing awareness of multiculturalism among students. Regarding the frequency of Internet use among students, many respondents stated "very often" $(11.2 \%)$ and "often" $(27.1 \%)$. They also believed the Internet had influenced them, with responses of "strongly agree" (16.8\%) and "somewhat agree" (29\%). The level of effect was stronger than that of society $(12.1 \%, 29 \%)$ and friends $(12.1 \%, 23.4 \%)$.

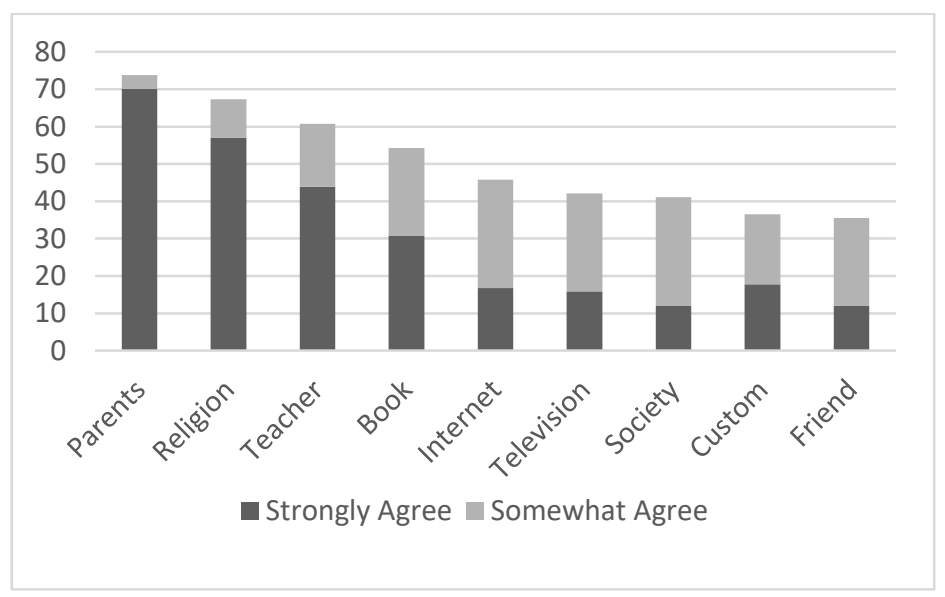

Figure 1. Factors Affecting Decision-making.

Table 1 suggests that the students had a relatively strong sense of ethnic, local, and national attachment. Ethnic attachment, however, was less strong than other aspects. Among ethnic groups, there were no significant differences 
in national attachment level. In Banks' (2017) notion of transformative citizenship, minority ethnic groups tend to have a weaker national identity, or "failed citizenship." Here, however, even minority-group students showed strong national attachment. At the same time, one might have to question the existence of reflective national identification (Banks, 2008).

Table 1

Respondents' Answers Regarding National/Ethnic/Local Attachment

\begin{tabular}{llll}
\hline Factor & $N$ & $M$ & $S D$ \\
\hline National & 99 & 4.91 & 0.289 \\
Attachment & & & \\
Ethnic Attachment & 82 & 4.39 & 0.75 \\
Local Attachment & 91 & 4.71 & 0.543 \\
\hline
\end{tabular}

Table 2 reports students' ethnic identity. In this study, students felt strongly attached to their ethnicity (4.39 in item 6), compared to spending time trying to learn more about their ethnic group (4.14 in item 1) and participating in activities to understand their ethnic background (4.12 in item 4). Talking about their ethnicity scored low (3.94 in item 5), while understanding ethnic group membership had the lowest score (3.53 in item 3 ). Thus, they felt a sense of belonging to their ethnic group but did not fully understand the role and meaning of belonging to an ethnic group.

Table 2

Respondents' Answers Regarding Ethnic Identity

\begin{tabular}{|c|c|c|c|}
\hline Question Item & $N$ & $M$ & $S D$ \\
\hline $\begin{array}{l}\text { 1. Spend time trying to find out more about my } \\
\text { ethnic group }\end{array}$ & 85 & 4.14 & 0.693 \\
\hline 2. Feel a strong sense of belongingness & 80 & 4.11 & 0.763 \\
\hline 3. Understanding of my ethnic group membership & 79 & 3.53 & 1.376 \\
\hline $\begin{array}{l}\text { 4. Often do things to understand my ethnic } \\
\text { background }\end{array}$ & 77 & 4.12 & 0.628 \\
\hline $\begin{array}{l}\text { 5. Talk to people to learn more about my ethnic } \\
\text { group }\end{array}$ & 79 & 3.94 & 1.244 \\
\hline 6. Attachment & 82 & 4.39 & 0.750 \\
\hline
\end{tabular}


Regarding perceptions of globalization (see Table 3), their perception of "Good for the economy" was highest (4.37 in item 1), while "Good for the labor market" (4.04 in item 2) and "Good for the nation" (4.29 in item 3) were relatively high. Negative perceptions regarding "Seeking national interest" were low (2.56 in item 4). Students thought they should seek win-win solutions in the global economy. The results indicate students' positive and healthy perceptions of globalization; they welcomed it and were not country-centric.

Table 3

Respondents' Answers Regarding Perceptions of Globalization

\begin{tabular}{llll}
\hline Question Item & $N$ & $M$ & $S D$ \\
\hline 1. Good for the economy & 86 & 4.37 & 0.575 \\
2. Good for the labor market & 84 & 4.04 & 1.207 \\
3. Good for the nation & 90 & 4.29 & 1.22 \\
4. Seeking national interest & 81 & 2.56 & 0.628 \\
5. Need for import control & 91 & 3.95 & 0.993 \\
6. Bad influence on culture & 81 & 3.07 & 1.16 \\
\hline
\end{tabular}

Meanwhile, regarding willingness to contribute to society as a reason for future job selection, respondents answering "strongly agree" to "for the nation" were the highest (44.9\%), followed by "for the world" (38.3\%) (see Figure 2). This indicates that many students had a strong sense of global citizenship.

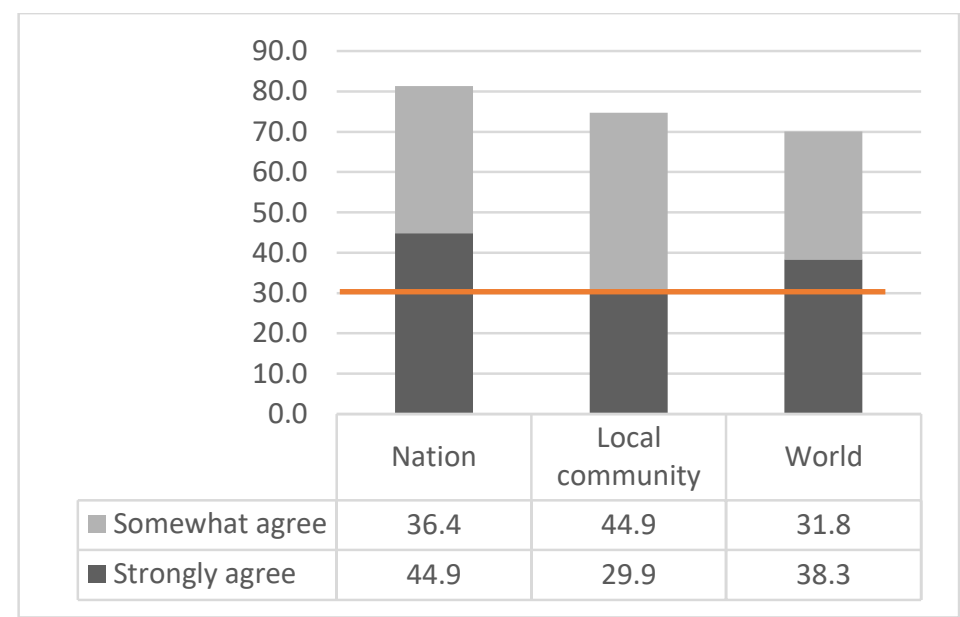

Figure 2. Respondents' Answers Regarding Willingness to Contribute.

This study's results with respect to students' social identity features and the factors affecting them can provide insight for improving multicultural education so that it may serve as transformative citizenship education. The 
survey showed that parents, religion, and teachers strongly affect students' views. Thus, teachers play a crucial role in helping students to overcome past conflicts and prevent future ones. In the comparison between national, local, and ethnic attachments, national attachment was the strongest, though ethnic attachment was strong as well. Students may take pride in their ethnic identity and be active members of their group. However, they might not fully understand their role as a member of an ethnic group. Once they have a family, they will usually gain a clearer image of their role in the group.

Regarding previous conflicts, Dayak and Madura expressed their role in their ethnic group in terms of seeking revenge or protecting their group according to carok and adat (Prevent Conflict, 2002). Multicultural education is expected to foster different values and knowledge to resolve conflicts or prevent future ones through legal and peaceful means. Then, it can become a transformative citizenship education that serves to build a multicultural democratic society (Banks, 2008). Since students showed a high sense of attachment and contribution to the nation rather than to their local community and ethnic group, there is a possibility for them to prevent conflict and maintain unity as a good nation. In the civic education of the national curriculum, students are taught multiculturalism as a pillar supporting the unity of the country. As Zembylas (2012) discussed, citizenship education could help children to reflect critically on the conditions of ethnic conflict and act on the basis of shared fates and compassion. However, Indonesian national civic education is currently weak, in terms of not fully providing critical analyses of domestic ethnic conflict. This is because the roots of the violence-namely, its complex social, historical, and political factors-are related to government policy. These aspects are sensitive issues at both the local and national levels.

The finding that students are open-minded about globalization and have a strong sense of contribution to the global society suggests that if their past local ethnic conflicts are described from a global perspective and utilized within the framework of transformative citizenship education (Banks, 2008, 2017), students may be able to critically analyze those conflicts and take appropriate action for the future.

\section{Conclusion}

Since teachers strongly affect students' opinions, multicultural education might have a high potential for overcoming past conflicts and fostering a new multicultural society without violence. Regarding the first dimension of multicultural education (Banks, 2004), the textbook tries to introduce not only majority cultures but also the culture of minorities and migrants in West Kalimantan. In practice, some good models were found, such as learning the Dayak worldview by studying the meaning of tattoo motifs and making ethniclanguage dictionaries. These could help students reflect on their negative 
images and experience making tools to improve respect for, and understanding of, other ethnic groups.

However, several problems remain. First, as a result of education officials' and parents' trauma and vague anxiety about multicultural education and its textbook, using the textbook is not as widespread as expected. Second, the textbook is limited in terms of breaking stereotypes. It contains many photos and descriptions of ethnic cultures that could affect students' perceptions regarding the "primitive" and "savage" aspects of Dayak and Madura culture relative to the "noble" and "sophisticated" Java (national majority) and Malay (local majority) cultures. Lastly, multicultural education remains limited in its ability to foster transformative citizenship to build a democratic multicultural society (Banks, 2008, 2017), especially because of its lack of teaching "knowledge construction" (Banks, 2004) and the ability to think critically about "structural violence" (Galtung, 1969) and ways to create a non-violent society.

A feasible solution is to reorganize the textbook from a global perspective toward transformative citizenship education. Regarding the first problem of trauma, there is much previous research: Zembylas $(2009,2013)$ recommended using critical emotional praxis as a productive form of engagement with trauma narratives. Lauritzen and Nodeland (2017) found that a top-down curriculum created a gap between the knowledge and perspectives of the pupils and the level of engagement by the curriculum and teachers. However, the textbook examined in this research was careful to avoid political narratives and focused only on improving "competences of empathetic understanding" (Zembylas, 2013, p. 105), through general examples of child victims; moreover, development and implementation of the textbook was not a top down process (Lauritzen \& Nodeland, 2017). Therefore, to change people's negative image, the textbook needs to improve trauma sensitivities and add "knowledge construction" (Banks, 2004), as well as presenting a new paradigm of transformative citizenship education from a global perspective. This will help people understand that multicultural education is not only about retaining traditional culture and history, but also about educating those students who will change and create a new multicultural democratic society with global perspectives.

As the data showed, students have a strong sense of attachment and contribution to their nation, as well as positive perceptions of globalization and a high sense of contribution to the global society. Meanwhile, students continue to attend ethnic and cultural activities without fully recognizing their own roles in their ethnic society. Based on this situation of students' social identity, analyzing the multiple factors in other countries' conflicts and building a peaceful society from a global perspective is recommended as a transformative citizenship approach (Banks, 2017) that can be applied to their own society.

A limitation of this study is that it did not include directly asking students about their thoughts on ethnic conflicts, stereotypes of other ethnic groups, and 
citizenship levels. However, students' social identity and their perceptions of the factors affecting them could explain the meaning of education for them. To facilitate the selection of textbook content and teaching practices, future work could examine students' perceptions of local conflicts, with sensitivity to the related issues of trauma and tension. Moreover, multicultural education needs to be flexibly developed under transformative citizenship education from a global perspective. Since it is difficult to implement multicultural education as an independent subject, flexible learning packages and indicators for improving education from transformative citizenship education will be more suitable for implementation (Banks, 2015). It is hoped that this study's results and recommendations will contribute to improving curricula and educational practices with the aim of creating a peaceful multicultural global society.

\section{Notes}

1. This work was supported by JSPS KAKENHI Grant Number 26381132.

2. I would like to express my appreciation to Mr. Utama Eka Jaya Putri, Associate Professor of the Sebelas Maret University, for his support in making connections with the NGO, schools, and teachers in Pontianak, West Kalimantan. I also wish to express my deep appreciation to the teachers and students who agreed to take part in my research.

\section{References}

Achwan, R., Nugroho, H., Prayogo, D., \& Hadi, S. (2005). Overcoming violent conflict: Volume 1, peace and development analysis in West Kalimantan, Central Kalimantan, and Madura. Jakarta, Indonesia: CPRU-UNDP, Lab Sosio, and BAPPENAS.

Aliansi untuk Perdamaian dan Rekonsiliasi (ANPRI). (2008). Multicultural education Kalimantan Barat for grade VII junior high school. Pontianak, Indonesia: Institute Dayakologi dan ANPRI.

Banks, J. A. (2004). Multicultural education: Historical development, dimensions, and practice. In J. A. Banks \& C. A. M. Banks (Eds.), Handbook of research on multicultural education (2 ed., pp. 3-29). San Francisco, CA: Jossey-Bass.

Banks, J. A. (2008). Diversity, group identity, and citizenship education in a global age. Educational Researcher, 37(3), 129-139.

Banks, J. A. (2009). Diversity and citizenship education in multicultural nations. Multicultural Education Review, 1(1), 1-28.

Banks, J. A. (2015). Cultural diversity and education: Foundations, curriculum, and teaching (6th ed.). New York, NY: Routledge. 
Banks, J. A., Orozco, M. S., \& Peretz, M. B (2016). Global migration, diversity, and civic education: Improving policy and practice. New York, NY: Teacher College Press.

Banks, J. A. (2017). Failed citizenship and transformative civic education. Educational Researcher, 46(7), 366-377.

Bertrand, J. (2004). Nationalism and ethnic conflict in Indonesia. Cambridge, UK: Cambridge University Press.

Creswell, J. W. (2013), Qualitative inquiry \& research design (3rd ed.). Thousand Oaks, CA: SAGE.

Fontana. G. (2016). Religious education after conflicts: Promoting social cohesion or entrenching existing cleavages? Compare: A Journal of Comparative and International Education, 46(5), 811-831.

Fanselow, F. (2015). Indigenous and anthropological theories of ethnic conflict in Kalimantan. ZINBUN, 45, 131-147.

Galtung, J. (1969). Violence, peace and research. Journal of Peace and Research, 6,167-184.

Gutmann, A. (2004). Unity and diversity in democratic multicultural education: Creative and destructive tensions. In J. A. Bankts (Ed.), Diversity and citizenship education: Global perspectives (pp. 71-96). San Francisco, CA: Jossey-Bass.

Hamada, K. (2013). Attitude toward globalization in East Asia: Analysis of four East Asian regions using EASS 2008 data. JGGS Research Service, 10, 105-115.

International Crisis Group. (2001). Communal violence in Indonesia: Lessons from Kalimantan. Asia Report 19, Jakarta/Brussels. Retrieved from https://d2071andvip0wj.cloudfront.net/19-communal-violence-inindonesia-lessons-from-kalimantan.pdf

Katou, T. (1993).「多様性の中の統一」への道, インドネシア[The Road to Unity, Indonesia]. In M. Tsuneji, Y. Shinji, \& I. Masa (Eds.) (pp. 25-34). Tokyo, Japan: Kawade Shobou Shinsha.

Lauritzen, S. M., \& Nodeland, T. S. (2017). What happened and why? Considering the role of truth and memory in peace education curricula. Journal of Curriculum Studies, 49(4), 437-455.

Lewicka, M. (2008). Place attachment, place identity, and place memory: Restoring the forgotten city past. Journal of Environmental Psychology, 28, 209-231.

Mansouri. F., (2009). Transformative pedagogies for critical difference and inclusive schooling. In N. Kassabgy \& A. Elshimi (Eds.), Sustaining excellence in "communicating across the curriculum": Cross-institutional experiences and best practices (pp. 164-189). Newcastle upon Tyne, UK: Cambridge Scholars Publishing. 
Nakaya, A. (1995). インドネシアにおける「地域科」に関する研究: 国民文化と民族文化の調整を中心に [A study of “muatan lokal” in Indonesian education: Regulation between national culture and ethnic culture]. 比較教育学研究 [Comparative Education], 21, 73-82.

Nakaya, A. (1997). インドネシアにおける地域科カリキュラムの機能に関す る批判的研究 [A critical study on the functions of the "local curriculum" (“muatan lokal”) in Indonesia]. 比較教育学研究 [Comparative Education], 23, 113-127.

Nakaya, A. (2004). Muatan lokal for the local community: A study of life and environment education subjects in Jakarta-PLKJ. Pacific Asian Education, 16(2), 38-48.

Nakaya, A. (2011). インドネシア・アンボンにおける本和な文化をつくるため の学校教育[School culture for creating peace culture in Ambon in Indonesia]. 総合学術 [Journal of Japan Society for Interdisciplinary Science], 10, 55-62.

Nakaya, A. (2015). インドネシア・アンボンにおける世代別アイデンティ ティの特徵と教育に関する考察 [Identity differences by generation and educational influence in Ambon, Indonesia]. 広島大学国際センター紀要 [Bulletin of the International Center Hiroshima University], 5, 35-49.

Obori, K. (2010). ローカル・アイデンティティの複合性--概念の使用法に関す る検討 [The complexity of local identity: An examination of the direction for uses of the concept]. 社會科學研究、東京大学社会科学研究所 [Journal of Social Science, Tokyo University], 61(5-6), 143-158.

Phinney, J., \& Ong, A. (2007). Conceptualization and measurement of ethnic identity: Current status and future directions. Journal of Counselling Psychology, 54(3), 271-281.

Prevent Conflict. (2002). Armed conflicts report Indonesia, Kalimantan, Project Ploughshares. Retrieved from http://www.justice.gov/sites/ default/files/eoir/legacy/2014/02/25/Indonesia_Kalimantan.pdf

Salomon, G., \& Cairns, E. (2010). Handbook on peace education. New York, NY: Psychology Press.

Scannell, L., \& Gifford, R. (2010). Defining place attachment: A tripartite organizing framework. Journal of Environmental Psychology, 30, 1-10.

Sleeter, C. E. (2016). Critical family history: Situating family within contexts of power relationships. Journal of Multidisciplinary Research, 8(1), 11-24.

Tanabe, S. (2010). ナショナルアイデンティティの国際比較 [International comparison on nation and identity], Tokyo, Japan: Keiou Gijuku Daigaku Shuppankai. 
Yuki, K. (2016). Modernization, social identity, and ethnic conflict. MRPA Paper No. 75748. Retrieved from https://mpra.ub.uni-muenchen.de/75748/ 1/MPRA_paper_75748.pdf

Zembylas, M. (2009). Inventing spaces for critical emotional praxis: The pedagogical challenges of reconciliation and peace. In C. McGlynn, M. Zembylas, Z. Bekerman, \& T. Gallagher, Peace education in conflict and post-conflict societies (pp. 183-197). New York, NY: Palgrave Macmillan.

Zembylas, M. (2012). Citizenship education and human rights in sites of ethnic conflict: Toward critical pedagogies of compassion and shared fate. Studies in Philosophy and Education, 31, 553-567.

Zembylas, M. (2013). Critical emotional praxis: Rethinking teaching and learning about trauma and reconciliation in schools. In P. P. Trifonas \& B.L. Wright (Eds.), Critical peace education (pp. 101-114). New York, NY: Springer.

\section{Author Contact}

Ayami Nakaya: anakaya@hiroshima-u.ac.jp

Hiroshima University, 739-8529 Hiroshima Prefecture, Higashi-hiroshima, Kagamiyama 1chome-5-2, Japan 